\title{
Penegakan Hukum Diwilayah Laut Maluku oleh Lantamal IX Ambon
}

\section{Lucia Charlota Octovina Tahamata}

Fakultas Hukum Universitas Pattimura, Ambon, Indonesia

@: luciatahamata69@gmail.com

: $\operatorname{xxxxxxxxxxxxx}$

Dikirim: 4/01/2021

\begin{tabular}{l}
\hline Info Artikel \\
Keywords: \\
Law Enforcement; In The Sea \\
Area; Lantamal IX. \\
Kata Kunci: \\
Penegakan Hukum; Laut \\
Aaluku; Lantamal IX \\
Ambon
\end{tabular}

Direvisi: 22/02/2021

\section{Abstract}

Introduction: Law enforcement in the sea area by Lantamal IX Ambon, is faced with, supporting factors and inhibiting factors.

Purposes of the Research: This study aims to determine and analyze how Lantamal IX Ambon conducts law enforcement in the Maluku sea area.

Methods of the Research: The research method used is a normative research method using a statute approach approach conceptual approach and analytical approach. Document study techniques and study analysis use qualitative analysis.

Results of the Research: The results showed that in order to achieve efficiency and effectiveness in deploying the force of the Navy, it is faced with budget constraints, technical conditions of defense equipment and the expected level of capability and escalation of threats, it is necessary to reform policies regarding law enforcement facilities and infrastructure towards improvements in accordance with science. and modernization today due to the reality of the geographical configuration of the country's territory in the form of an archipelago with 2/3 of its territory being water, of course logically Indonesia needs a strong and reliable Navy. There is an overlap in legal and institutional arrangements at sea, so it is necessary to synergize with the institutional aspects of law enforcement officials who have the authority.

\begin{tabular}{l} 
Abstrak \\
\hline Latar Belakang: Penegakan hukum diwilayah laut oleh Lantamal \\
IX Ambon, diperhadapkan dengan, faktor pendukung dan faktor \\
penghambat. \\
Tujuan Penelitian: Penelitian ini bertujuan untuk mengetahui dan \\
menganalisa bagaimana Lantamal IX Ambon melakukan \\
penegakan hukum diwilayah laut Maluku. \\
Metode Penelitian: Penelitian yang digunakan adalah metode \\
penelitian normatif dengan mengunakan pendekatan statute \\
aproach conceptual approach serta analytical approach. Teknik \\
studi dokumen serta analisis kajian mengunakan analisis kualitatif. \\
Hasil Penelitian: Hasil penelitian menunjukan bahwa Agar \\
tercapai efisiensi dan efektivitas dalam menggelar kekuatan \\
Angkatan Laut dihadapkan kepada keterbatasan anggaran, \\
kondisi teknis alutista dan tingkat kemampuan yang diharapkan \\
serta eskalasi ancaman, perlu dilakukan pembaharuan kebijakan \\
yang menyangkut sarana dan prasarana penegakan hukum \\
menuju kepada perbaikan yang sesuai dengan ilmu pengetahuan \\
dan meodernisasi dewasa ini karena realitas konfigurasi geografi \\
wilayah negara yang berbentuk kepulauan dengan 2/3 bagian \\
wilayahnya adalah perairan tentunya secara logika Indonesia \\
membutuhkan Angkatan Laut yang kuat dan handal. Adanya
\end{tabular}


tumpang tindih pengaturan hukum dan kelembagaan dilaut, sehingga perlu sinergi dilakukan terhadap aspek kelembagaan aparat penegak hukum yang mendapat kewenangan.

\section{A. PENDAHULUAN}

Indonesia adalah negara kepulauan terbesar didunia dengan jumlah pulau sebanyak 17.499 pulau, dan luas wilayah 70 \% berupa laut. Status Indonesia sebagai negara kepulauan sudah dikumandangkan pada saat Deklarasi Djuanda pada 13 desember 1957. Pengakuan internasional terhadap kedaulatan negara Republik Indonesia sebagai negara kepulauan telah disetujui pada konvensi Hukum Laut ketiga (United nations Convention on the law of the sea) tahun 1982 yang selanjutnya diratifikasi malalui Undang-Undang Nomor 17 Tahun $1985 .{ }^{1}$

Wilayah laut Indonesia menyimpan banyak potensi kekayaan laut yang sangat berlimpah. Hal tersebut dikarenakan Indonesia memiliki perairan laut yang sangat luas. Kawasan tersebut diperkirakan menyimpan kekayaan sumberdaya ikan sebesar 6,4 juta ton per tahun namun upaya ekploitasi berlebihan dan aksi pencurian ikan yang dilakukan oleh nelayan asing yang semakin marak mengancam potensi kekayaan tersebut. Sejak tahun 2005, operasi kapal pengawasan SDKP (sumber daya kelautan perikanan) telah behasil menangkap lebih kurang 1.343 kapal perikanan pelaku illegal fishing, teridiri atas 58 Kapal Perikanan Asing (KIA) dan 585 Kapal Perikanan Indonesia (KII). Selama 20162, KKP telah melakukan pemeriksaan sebanyak 4.326 kapal perikanan. Dari jumlah tersebut, kapal yang ditangkap sejumlah 112 kapal perikanan diduga melakukan tindak pelanggaran, 70 merupakan kapal asing, dan 42 kapal ikan Indonesia. Versi lain menyebutkan, menurut pusat Data dan Informasi KIARA, selama kurang waktu 10 tahun dari 2006 hingga 2016 grafik illegal fishing mengalami naik turun tidak stabil. Namun data trakhir pada 2016, terdapat 75 kasus. Jumlah illegal fishing paling tinggi terjadi pada tahun 2007, yaitu sebanyak 522 kasus. Sementara dari rekap data Hasil Operasi Kamla TNI AL tahun 2016 terdapat 17 kapal asing yang melakukan illegal fishing. Dari seluruh data yang dapat disimpulkan bahwa pelanggaran illegal fishing paling banyak dilakukan oleh kapal nelayan asing. ${ }^{3}$

Berkembangnya serta adanya kepentingan dari negara-negara maju terhadap kebutuhan akan sumber daya kelautan, dapat mengakibatkan suatu negara tidak mengindahkan dan mentaati seluruh ketentuan-ketentuan yang ada baik yang telah disepakati antara negara. Sering terjadi diwilayah perairan Maluku yang dapat menganggu stabilitas keamanan dalam negeri, yang antara lain terjadi penangkapan ikan secara ilegal.

Pada 29 Maret 2017 , dua kapal ikan berbendera asing yakni kapal ikan Sino 26 dan kapal ikan Sino 35 melakukan penangkapan ikan secara ilegal di perairan Maluku. Kapal tersebut ditangkap karena surat izin penangkapan ikan (SPI) telah dicabut/dibekukan dan tidak berlaku lagi , serta dua kapal ikan tersebut mengunakan kantong jaring berlapis.yang ditangkap oleh KRI Ahmad Yani 351 berlayar dilaut Arufura .Penangkapan oleh Lantamal IX, proses selanjutnya diserahkan kepada instansi yang lain.

Pasal 1 ayat (3) Undang-Undang Dasar Negara Republik Indonesia Tahun 1945 menegaskan bahwa: "Negara Indonesia adalah negara hukum". Maksudnya adalah bahwa Indonesia adalah negara yang menegakkan supremasi hukum untuk menegakkan kebenaran

\footnotetext{
1 Dikdik Mohammad Sodik, Hukum Laut Internasional (Bandung: Refika Aditama, 2011), h. 41.

2 Aditya Taufan Nugraha and Irman, "Perlindungan Hukum Zona Ekonomi Eksklusif (ZEE) Terhadap Eksistensi Indonesia Sebagai Negara Maritim," Jurnal Selat 2, no. 1 (2014): 156-67, https://ojs.umrah.ac.id/index.php/selat/article/view/120.

3 Nugraha and Irman.Ibid.
} 
dan keadilan dan tidak ada kekuasaan yang tidak dipertanggung-jawabkan ${ }^{4}$. Hukum sendiri dapatlah didefinisikan sebagai seperangkat kaidah atau ukuran yang tersusun dalam satu sistem, yang menentukan apa yang boleh dan apa yang tidak boleh dilakukan oleh manusia sebagai warga masyarakat dalam kehidupan bermasyarakatnya, yang bersumber baik dari masyarakat sendiri maupun dari sumber lain, yang diakui berlakunya oleh otoritas tertinggi dalam masyarakat tersebut, serta benar-benar diberlakukan oleh warga masyarakat (sebagai satu keseluruhan) dalam kehidupannya, dan jika kaidah tersebut dilanggar akan memberikan kewenangan bagi otoritas tertinggi untuk menjatuhkan sanksi yang sifatnya eksternal ${ }^{5}$. Melalui hukum positif nasionalnya, Indonesia senantiasa berupaya demi mewujudkan tujuan nasionalnya yakni melindungi segenap bangsa dan seluruh tumpah darah Indonesia, memajukan kesejahteraan umum, mencerdaskan kehidupan bangsa, dan ikut serta melaksanakan ketertiban dunia yang berdasarkan kemerdekaan, perdamaian abadi, dan keadilan sosial.

Untuk mewujudkan tujuan nasional tersebut, maka syarat utamanya adalah Indonesia, sebagai negara kepulauan (archipelagic state) terbesar di dunia, perlu secara konsisten menegakkan kedaulatan negara, mempertahankan keutuhan wilayah negara kesatuan Republik Indonesia, dan keselamatan segenap bangsa dari ancaman militer serta ancaman bersenjata terhadap keutuhan bangsa dan negara. Oleh sebab itu maka Tentara Nasional Indonesia (TNI) sebagai alat pertahanan negara kesatuan Republik Indonesia, bertugas melaksanakan kebijakan pertahanan negara untuk menegakkan kedaulatan negara, mempertahankan keutuhan wilayah, dan melindungi keselamatan bangsa, menjalankan operasi militer untuk perang dan operasi militer selain perang, serta ikut secara aktif dalam tugas pemeliharaan perdamaian regional dan internasional. Tugas pokok TNI sendiri ialah menegakkan kedaulatan negara, mempertahankan keutuhan wilayah negara kesatuan Republik Indonesia yang berdasarkan Pancasila dan Undang-Undang Dasar Negara Republik Indonesia Tahun 1945, serta melindungi segenap bangsa dan seluruh tumpah darah Indonesia dari ancaman dan gangguan terhadap keutuhan bangsa dan negara.

UU No. 32 Tahun 2014 tentaang Kelautan, merupakan bagian dari upaya untuk memberikan kepastian hukum dalam penegakan hukum dilaut yang sekaligus mampu menyelesaikan masalah tumpang tindihnya sistem penegakan hukum di wilayah laut. Keberadaan Undang-Undang Nomor 32 Tahun 2014 tentang Kelautan ketika diundangkan diharapkan tidak akan menimbulkan suatu masalah yang baru, namun diharapkan justru akan membantu penyederhanaan atas permaslaahan-permaslaahan yang dihadapi dalam rangka penegakan hukum di wilayah laut. Dengan demikian diharapkan akan lebih baik dalam memberikan kejelasan hukum bagi institusi yang mempunyai wewenang dalam wilayah laut serta dapat memberikan kepastian hukum kepada para pelaku usaha, pengguna jasa, dan pelaku jasa transportasi laut.

TNI Angkatan Laut sebagai komponen utama pertahanan negara di wilayah perairan berkewajiban untuk menjaga kedaulatan negara dan integritas wilayah NKRI, mempertahankan stabilitas keamanan di wilayah perairan, melindungi sumber daya alam di wilayah perairan dari berbagai bentuk gangguan keamanan dan pelanggaran hukum di wilayah perairan yurisdiksi nasional Indonesia. Konsepsi dasar terhadap perwujudan keamanan di wilayah perairan pada hakikatnya memiliki dua dimensi yaitu penegakan kedaulatan dan penegakan keamanan yang saling berkaitan satu dengan lainnya.

4 Majelis Permusyawaratan Rakyat Republik Indonesia, "Panduan Permasyarakatan Undang-Undang Dasar Republik Indonesia Tahun 1945" (Jakarta, 2010), h. 46.

5 Achmad Ali, Menguak Tabir Hukum (Suatu Kajian Filosofis Dan Sosiologis) (Jakarta: Toko Gunung Agung, 2002), h. 35. 
Tugas Pokok Lantamal IX selaku Satuan kerja dibawah Komando Armada RI Kawasan Timur (Koarmatim) sebagai berikut:

a) Tugas pokok: menyelenggarakan dukungan logistik administrasi bagi unsur-unsur Koarmatim dan operasional TNI AL yang lainnya (KRI, Pesud, dan Marinir) yang sedang melaksanakan kegiatan operasi di wilayah kerja Lantamal IX. Melaksanakan pembinaan potensi maritim menjadi kekuatan pertahanan negara di laut serta melaksanakan operasi dan patroli dalam rangka penegakan kedaulatan dan hukum di laut yuridiksi nasional dengan memanfaatkan rangka sarana dan prasarana yang dimiliki pangkalan sendiri maupun satuan samping.

b) Tugas tambahan: menyelenggarakan dukungan bagi kesatuan Non TNI AL sesuai fungsi dan kebutuhan, meliputi tugas-tugas kepada Pemerintah daerah dan tugastugas Militer selain perang (OMSP) dilingkup kedaerahan.

Maka dibutuhkan kejelasan mengenai penegakan hukum di wilayah laut Maluku oleh Lantamal IX Ambon.

\section{B. METODE PENELITIAN}

Penelitian ini mengunakan penelitian hukum normatif, mengunakan pendekatan statute approach, conceptual approach, serta analitical approach. Teknik penyelusuran bahan hukum, mengunakan teknik studi dokumen serta analisis, kajian mengunakan analisis kualitatif.

\section{HASIL DAN PEMBAHASAN}

Negara-negara yang sedang berkembang akan berusaha melakukan penguasaan atas laut guna perluasan yurisdiksi untuk melindungi kepentingan-kepentingannya, apalagi kemajuan teknologi yang semakin maju mendorong adanya keinginan untuk memanfaatkan sumber daya alam yang akan dapat memberikan keuntungan bagi suatu negara. Oleh karena itu, untuk mengimplementasikan keinginan-keinginan dan mengatur kepentingankepentingan semua negara-negara internasional agar tidak terjadi tumpang tindih antar kepentingan tersebut, maka diadakanlah konvensi-konvensi hukum laut internasional, dimana terakhir telah berhasil dilaksanakannya Konvensi Hukum Laut Perserikatan Bangsa-Bangsa (PBB) 1982 yang telah menghasilkan United Nations Convention on the Law of the Sea (UNCLOS). Salah satu ketentuan UNCLOS 1982 adalah mengatur terkait batas-batas maritim. UNCLOS 1982 mengatur pembagian laut yang dibagi menjadi tiga bagian, yaitu wilayah laut di bawah kedaulatan negara, wilayah laut di bawah yurisdiksi negara, dan wilayah laut di luar yurisdiksi negara.

Wilayah laut yang berada di bawah kedaulatan negara adalah bagian laut dimana suatu negara mempunyai hak penuh dalam wilayah tersebut dan mempunyai wewenang tertinggi untuk menguasai wilayah tersebut. Daerah yang menjadi kedaulatan negara terdiri dari laut teritorial (territorial sea), perairan pedalaman (Internal waters), perairan kepulauan (Archipelagic sea), sebagaimana yang terdapat dalam Pasal 3 ayat (1) Undang-Undang Nomor 6 Tahun 1996 tentang Perairan Indonesia. Wilayah tersebut disebut juga sebagai wilayah perairan Indonesia. Hal ini juga ditegaskan dalam Pasal 1 Angka (4) Undang-Undang Nomor 6 Tahun 1996 tentang Perairan Indonesia yang menyatakan bahwa Perairan Indonesia adalah laut teritorial Indonesia beserta perairan kepulauan dan perairan pedalamannya.

Laut teritorial merupakan perairan nasional berupa jalur laut yang terletak di sepanjang pantai dari garis pangkal dan dibatasi oleh garis batas luar (oute limit) laut territorial. Pengertian tersebut merupakan pengertian secara umum karena pada saat itu belum ada 
penentuan lebar dari laut teritorial. Setelah Konvensi Hukum Laut 1982 ditetapkan barulah dapat dirumuskan secara pasti lebar laut teritorial, dimana setiap negara mempunyai hak untuk menetapkan lebar laut teritorialnya tidak melebihi 12 mil laut yang diukur dari garis pangkal dan dibatasi oleh garis yang jarak setiap titiknya dari yang terdekat dari garis pangkal, sama dengan lebar laut territorial. Laut teritorial merupakan perairan nasional berupa jalur laut, dimana jalur tersebut tidak melebihi 12 mil laut yang diukur dari garis pangkal dan dibatasi oleh garis batas luar (outer limit) laut teritorial. Sedangkan Indonesia merupakan negara kepulauan oleh karena itu laut teritorial Indonesia diukur dari garis pangkal kepulauan Indonesia.

Perairan pedalaman adalah perairan pada sisi darat garis pangkal laut teritorial merupakan bagian perairan pedalaman negara tersebut. Sedangkan dalam Pasal 3 ayat (4) Undang-Undang Nomor 6 Tahun 1996 tentang Perairan Indonesia disebutkan bahwa, Perairan Pedalaman Indonesia adalah semua perairan yang terletak pada sisi darat dari garis air rendah dari pantai-pantai Indonesia, termasuk kedalamnya semua bagian dari perairan yang terletak pada sisi darat dari suatu garis penutup.

Perairan Kepulauan adalah perairan yang ditarik oleh garis pangkal kepulauan, yang ditarik dari titik-titik terluar pulau-pulau utama dan suatu daerah dimana perbandingan daerah perairan dan daerah daratan adalah satu berbanding satu dan sembilan berbanding satu (1:1 dan 9:1). Panjang garis pangkal tersebut tidak boleh melebihi 100 mil laut kecuali $3 \%$ dari jumlah seluruh garis pangkal yang mengelilingi setiap kepulauan dapat melebihi panjang tersebut sampai maksimum 125 mil laut. Penarikan garis pangkal ini tidak boleh menyimpang terlalu jauh dari konfigurasi umum, dan juga tidak boleh ditarik ke dan dari elevasi surut (low-tide elevations) kecuali terdapat mercusuar atau instalasi permanen dan jaraknya tidak melebihi lebar laut teritorial, yaitu 12 mil.

Pasal 47 UNCLOS 1982 Negara kepulauan tidak boleh menarik garis pangkal itu yang memotong laut teritorial, atau zona ekonomi eksklusif negara lain. Setelah menggunakan atau menarik garis pangkal kepulauan berdasarkan ketentuan tersebut baru dapat ditentukan mana yang menjadi perairan kepulauan negara yang bersangkutan. Dimana perairan kepulauan adalah perairan yang ditutup oleh garis pangkal kepulauan, tanpa memperhatikan kedalaman atau jaraknya dari pantai sebagaimana yang diatur dalam Pasal 49 ayat (1) UNCLOS 1982.

Untuk memberikan gambaran faktor pendukung dalam penegakan hukum di laut yuridiksi Indonesia, maka diperlukan adanya landasan hukum yang dikemukan dalam bagian ini, tidak hanya terbatas pada landasan hukum yang berkaitan dengan penegakan hukum di perairan yuridikasi Indonesia saja, melainkan seluruh peraturan perundangundangan yang menjadi landasan yuridis penegakan hukum di laut, baik dalam bentuk undang-undang atau peraturan pelaksanaannya. Faktor pendukung dan penghambat penegakan hukum adalah sebagai berikut:

1) Faktor-faktor pendukung penegakan hukum dilaut.

Adanya seperangkat aturan (norma hukum) yang mengatur tentang tindak pidana Di laut yaitu:

a) TZMKO. Ordonansi Laut Teritorial dan Lingkungan Laut Larangan (Territoriale Zee en Maritime Kringen Ordonantie) 1939 Stbl.1939 Nomor 442.

b) Undang-Undang Nomor 8 Tahun 1981 tentang KUHAP jo Peraturan Pemerintah Nomor 27 Tahun 1983 tentang Pelaksanaan KUHAP.

c) Undang-Undang Nomor 5 Tahun 1983 tentang Zona Ekonomi Eksklusif Indonesia (ZEEI).

d) Undang-Undang Nomor 17 Tahun 1985 tentang Pengesahan UNCLOS 1982. 
e) Undang-Undang Nomor 5 Tahun 1990 tentang Konservasi Sumber Daya Hayati dan Ekosistemnya.

f) Undang-Undang Nomor 6 Tahun 1996 tentang Perairan Indonesia.

g) Undang-Undang Nomor 45 Tahun 2009 tentang perubahan Undang-Undang Nomor 31 Tahun 2004 tentang Perikanan.

h) Undang-Undang Nomor 34 Tahun 2004 tentang Tentara Nasional Indonesia.

i) Undang-Undang Nomor 17 Tahun 2008 tentang Pelayaran.

j) Undang-Undang Nomor 43 Tahun 2008 tentang Wilayah Negara

2) Faktor-faktor penghambat.

a) Bahwa dalam upayanya melakukan pemberantasan tindak pidana diwilayah laut, meskipun pemerintah telah melakukan berbagai upaya, seperti melalui kebijakan legislasi maupun dengan membentuk forum atau badan koordinasi, namun pemberantasan tindak pidana di wilayah perairan laut tidak terlepas dari berbagai permasalahan yang dihadapi, termasuk dalam hal ini permasalahan yang dihadapi TNI Angkatan Laut sebagai salah satu unsur penegak hukum di wilayah perairan laut. Guna melakukan analisis hambatan yang dihadapi oleh TNI Angkatan Laut dalam melakukan pemberantasan tindak pidana di wilayah perairan laut Indonesia, patut menjadi acuan adalah teori yang dikemukakan oleh Soerjono Soekanto, mengenai faktor-faktor yang mempengaruhi penegakan hukum meliputi hukum itu sendiri (subtansi hukum, aparat hukum, sarana atau fasilitas), masyarakat dan kebudayaan dan teori Friedman Lawrence M. Friedman ${ }^{6}$ mengenai efektifitas hukum yang meliputi struktur, substansi, dan budaya hukum.

b) Saat ini pembangunan dibidang kelautan di Indonesia masih diwarnai konflik kepentingan dan kewenangan, baik konflik secara vertikal, pusat dan daerah maupun konflik horizontal antar pelaku usaha atau antar sektor. Penegakan hukum di laut masih bersifat sektoral, ada beberapa instansi yang di beri wewenang untuk penegakan hukum di laut yaitu TNI AL, Polri, Ditjen imigrasi, Ditjen bea cukai, Ditjen perhubungan laut, Ditjen Perikanan, Ditjen kehutanan, ada instansi yang mempunyai aset operasional, dan ada yang tanpa aset, ada juga yang mempunyai divisi intelijen dan ada pula yang seadanya. Namun satu hal yang perlu disadari adalah, masing-masing instansi tersebut bekerja dengan strategi sendiri-sendiri dengan demikian ada beberapa strategi (Ends, Means, Ways) bekerja di area operasi yang sama. Apabila situasi ditinjau dari kacamata manajemen, maka dapat disimpulkan bahwa Indonesia menganut System multi agency, Single task.

Kenyataan di laut menunjukkan banyak badan penegak hukum yang tidak sepenuhnya mampu memberikan jaminan agar hukum di patuhi, dan jelas juga tidak akan mampu bertindak apabila terjadi insiden yang disertai kekerasan. Contoh Insiden Patroli DKP menghadapi Polisi laut diraja Malaysia, benar-benar peristiwa yang memprihatinkan bila tidak dikatakan sebagai memalukan, maka dari itu kedepan patrol-patroli perbatasan harus dilakukan oleh unsur operasional TNI Angkatan laut, karena telah memang disiapkan menghadapi situasi kedaruratan dan aksi provoaktif negara lain.

Menurut Laksda Agung Pramono Panglima Armada RI Kawasan Timur dalam Makalahnya "kebijakan strategis penegakan hukum dilaut dan pengamanan perairan yuridiksi nasional RI wilayah timur dihadapkan tantangan perkembangan lingkungan strategis yang semakin dinamis" adalah dengan cara-cara sebagai berikut:

6 Lilik Mulyadi, Bunga Rampai Hukum Pidana Perspektif Teoretis Dan Praktik (Bandung: Alumni, 2008), h. 410. 
1) Meningkatkan pelanggaran dilaut dengan penerapan skala prioritas di perairan perbatasan dan jalur-jalur laut strategis serta perairan rawan selektif. Untuk menunjang upaya pengawasan dan pengamanan dengan mengembangkan pola operasional laut dengan meningkatkan kemampuan pangkalan dan pos-pos TNI AL terdekat serta menghadirkan unsur-unsur laut dan udara TNI AL dalam rangka mewujudkan pengendalian laut di wilayah laut tersebut. Unsur-unsur yang berada di lantamal dengan sarana dan patroli keamanan laut di wilayah sekitarnya yang menjadi kewenangannya.

2) Pengawasan atas daerah-daerah perbatasan memang memerlukan kerjasama dan koordinasi dengan negara-negara tetangga agar pengawasan yang dilakukan oleh indonesia dapat memperoleh hasil yang optimal. Dalam beberapa hal pengawasan tersebut dapat dilakukan melaui kerjasama Coordinate patrol, joint patrol, joint exercise, exchange of intelligence. Dan dalam hal-hal tertentu juga bisa melaui kesepakatan tentang hot persuit.

3) Melaksanakan operasi keamanan laut oleh unsur-unsur Koarmatim, yang digelar dalam rangka menaggulangi kerawanan laut diwilayah laut tertentu, selanjutnya para Komandan pangkalan untuk melakukan sosialisasi tentang operasi yang dilakukan oleh TNI AL di wilayah kerjanya masing-masing, dengan harapan agar Pemda setempat mengerti tentang kondisi wilayah kerjanya sehingga ketika membuat peraturan daerah tidak bertentangan dengan aturan yang lebih tinggi.

4) Lanal dan Pos TNI AL di bawah jajaran Lantamal melaksanakan patroli keamanan laut dengan sarana yang ada diwilayah kerja masing-masing sebagai upaya mengeleminasi terjadinya tindak illegal dilaut, disamping itu dengan kehadiran pelaksanaan patroli Patkamla dibeberapa wilayah kerja Lanal maupun Pos TNI AL dapat memberikan pencegahan terhadap niat dan upaya terjadinya tindak pelanggaran hukum dilaut.

5) Perwira TNI AL yang berada di KRI/KAL dan Pangkalan agar bekerja sama dengan satuan udara dalam melaksanakan penegakan hukum secara professional dan terukur selalu mengikuti perkembangan lingkungan strategi karena di lapangan menuntut kemampuan pemahaman atas diterbitkannya berbagai aturan perundang-undangan yang bersifat dinamis

\section{P E N U T U P}

Dengan dilakukan berbagai upaya pemberantasan tindak pidana di wilayah perairan laut, akan tetapi permasalahan penanganan tindak pidana di wilayah perairan laut Maluku sampai saat ini masih dirasakan kurang efektif dan kurang optimal, yang salah satunya disebabkan oleh adanya hambatan-hambatan yang dihadapi oleh Lantamal IX Ambon, hambatan tersebut meliputi, hambatan prosedur penegakan hukum, substansi hukum, fasilitas dan prasarana penegakan hukum serta keterbatasan anggaran.

\section{REFERENSI}

Ali, Achmad. Menguak Tabir Hukum (Suatu Kajian Filosofis Dan Sosiologis). Jakarta: Toko Gunung Agung, 2002.

Majelis Permusyawaratan Rakyat Republik Indonesia. "Panduan Permasyarakatan UndangUndang Dasar Republik Indonesia Tahun 1945." Jakarta, 2010.

Mulyadi, Lilik. Bunga Rampai Hukum Pidana Perspektif Teoretis Dan Praktik. Bandung: Alumni, 2008. 
Nugraha, Aditya Taufan, and Irman. "Perlindungan Hukum Zona Ekonomi Eksklusif (ZEE) Terhadap Eksistensi Indonesia Sebagai Negara Maritim." Jurnal Selat 2, no. 1 (2014): 156-67. https://ojs.umrah.ac.id/index.php/selat/article/view/120.

Sodik, Dikdik Mohammad. Hukum Laut Internasional. Bandung: Refika Aditama, 2011. 